\title{
Intensitas Penggunaan Media Sosial, Kebiasaan Olahraga, dan Obesitas Pada Remaja Di SMA Negeri 6 Surabaya Tahun 2019
}

\section{Intensity of Social Media Usage, Exercise Habits, and Obesity among Adolescent in Senior High School 6 Surabaya 2019}

\author{
Fransiska Sabatini Setiawati*1, Trias Mahmudiono ${ }^{2}$, Nadia Ramadhani ${ }^{3}$, Khairina Fadiah Hidayati ${ }^{4}$
}

\begin{abstract}
ABSTRAK
Latar Belakang: Aktivitas fisik merupakan faktor eksternal terbesar penyebab obesitas pada remaja. Prevalensi remaja gemuk di Indonesia mengalami peningkatan dari tahun 2013-2018. Gaya hidup kurang gerak cenderung terus meluas dalam masyarakat berteknologi maju. Peningkatan penggunaan media sosial, telah mengurangi jumlah waktu remaja untuk berolahraga.

Tujuan: Menganalisis hubungan antara intensitas penggunaan media sosial dan kebiasaan olahraga serta kaitannya dengan obesitas pada siswa/i SMAN 6 Surabaya.

Metode: Desain penelitian ini adalah cross sectional. Populasi penelitian adalah seluruh siswa/i kelas X dan XI SMAN 6 Surabaya sebanyak 614 orang. Sampel penelitian sebanyak 133 siswa/i yang dipilih dengan menggunakan cluster random sampling berdasarkan kelompok kelas X dan XI di SMAN 6 Surabaya. Data pada penelitian ini meliputi data karakteristik responden, kebiasaan olahraga dan intensitas penggunaan media sosial menggunakan kuesioner, serta status gizi berdasarkan pengukuran IMT/U sesuai standar World Health Organization (WHO) tahun 2005. Data dianalisis menggunakan uji korelasi Spearman.

Hasil: Sebagian besar responden memiliki kebiasaan olahraga yang tergolong rendah $(52,6 \%)$ sedangkan, intensitas penggunaan media sosial tergolong tinggi $(57,1 \%)$. Terdapat responden yang memiliki status gizi lebih $(21,1 \%)$ dan kurang $(6,8 \%)$ meskipun, sebagian besar dari mereka memiliki status gizi normal (72,2\%). Ada hubungan yang signifikan antara intensitas penggunaan media sosial dengan kebiasaan olahraga $(p=0,000)$ dengan $(r=-0,475)$ semakin tinggi intensitas penggunaan media sosial maka semakin rendah kebiasaan olahraga pada remaja.

Kesimpulan: Tingginya intensitas penggunaan media sosial berhubungan dengan rendahnya kebiasaan olahraga pada siswa/i SMAN 6 Surabaya..
\end{abstract}

Kata kunci: olahraga, media sosial, obesitas, remaja

\section{ABSTRACT}

Background: Physical activity is the external factors which has a siginficant corellation with obesity among adolecscents. The prevalence of obese adolescents in Indonesia has increased from 2013-2018. Sedentary lifestyle tends to expand largely in a high-tech society. The amount of time spent for social media usage has decreased their ability to do physical activity.

Objectives: The research purpose to analyze corelation between intensity of social media usage and sport habits Senior High School 6 Surabaya students.

Methods: The study was analytic observation with cross sectional study design. The population were students in $10^{\text {th }}$ and $11^{\text {th }}$ grade in Senior High School 6 Surabaya in total 614 people. Sample as determined by cluster random sampling and 133 sample were chosen. The data collected include the characteristic of sample sport habist and social media intensity usage through administered questionnaire, and nutritional status based on BMI/Age calculation in WHO Antro 2005. Data was analyzed by Spearman test.

Results: Most of students have low level in sport habits (52.6\%), while the intensity of social media use was high (57.1\%). There were respondents with overweight (21.1\%) and underweight (6.8\%), although the most of them had normal nutritional status (72.2\%). There was significant relationship between social media intensity usage and sport habits among students in SMAN 6

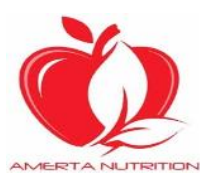

(C)2019. Fransiska, dkk. Open access under CC BY - SA license.

Received: 21-05-2019, Accepted: 10-07-2019, Published online: 09-9-2019.

doi: 10.20473/amnt.v3.i3.2019.142-148, Joinly Published by IAGIKMI \& Universitas Airlangga 
Surabaya $(p<0.001)$ with $(r=-0.608)$ this showed that the higher the intensity of the usde of social media, the lower the exercise habits in adolescents.

Conclusions: The high intensity of social media use is related to the low exercise habits of students of SMAN 6 Surabaya

Keywords: sports, social media, obesity, adolescent

*Koresponden:

fransiskasetiawati19@gmail.com

1,2,3,4Prodi S-1 Gizi Fakultas Kesehatan Masyarakat Universitas Airlangga, Kampus C Mulyorejo, 60115, Surabaya, Indonesia

\section{PENDAHULUAN}

Perubahan dapat terjadi dengan pesat di usia remaja baik pertumbuhan fisik, pertumbuhan kognitif, dan psikososial atau tingkah laku ${ }^{1}$. Waktu terjadinya puncak pertumbuhan terjadi saat masa remaja. Pertumbuhan yang pesat di usia remaja berpengaruh terhadap perkembangan komposisi tubuh remaja, perubahan pada berat badan dan juga masa tulang, serta aktivitas fisik, sehingga kondisi ini membuat kebutuhan gizi pada remaja ikut berubah².

Permasalah gizi pada masa remaja diantaranya yakni gizi kurang, gizi lebih, dan obesitas ${ }^{3}$. Berdasarkan data RISKESDAS 2018, di Indonesia remaja kurus berusia 13-15 tahun prevalensinya yakni6,8\% sedangkan, remaja gemuk prevalensinya sebesar $11,2 \%$. Remaja kurus berusia 16-18 tahun prevalensinya yakni $6,7 \%$ sedangkan, remaja gemuk prevalensinya sebesar 9,5\%. Prevalensi remaja gemuk di Indonesia mengalami peningkatan dibandingkan tahun 2013, prevalensi gemuk pada remaja 13-15 tahun meningkat sebanyak $0,4 \%$ sedangkan, prevalensi gemuk remaja usia 16-18 tahun meningkat sebanyak 2,2\%, dan pada remaja kurus relatif mengalami penurunan dibandingkan pada 2013. Provinsi Jawa Timur termasuk dalam provinsi dengani prevalensi remaja gemuk melebihi prevalensi nasional. Pada remaja usia gemuk13-15 tahun di Jawa Timur prevalensinya sebesar $13,3 \%$ dan $11,3 \%$ untuk usia 16-18 tahun $^{3}$.

Banyak faktor yang dapat mempengaruhi terjadinya obesitas pada remaja, yakni faktor internal dan eksternal. Faktor eksternal meliputi konsumsi makan, pengetahuan gizi, tingkat pendidikan, lingkungan sosial budaya, dan aktivitas fisik. Sedangkan, faktor internal diantara adalah usia, jenis kelamin, kondisi fisik, dan penyakit infeksi. Faktor eksternal merupakan faktor terbesar yang berperan dalam menyebabkan terjadinya obesitas, sedangkan faktor internal hanya menyumbang sebesar $10 \%{ }^{4}$. Aktivitas fisikyang rendah merupakan faktor eksternal yang paling berpengaruh besar pada terjadinya obesitas $^{5}$. Olahraga merupakan salah suatu bentuk aktivitas fisik yang menyumbang pengeluaran energi sebesar $20-50 \%$. Setiap melakukan olahraga terjadi pembakaran atau peningkatan metabolisme di dalam tubuhyang membuat tubuh menjadi panas dan berkeringat ${ }^{6}$. Durasii atau lamanya olahraga dan frekuensi olahraga yang sesuai akan memberikan manfaat baik bagi tubuh7. Olahraga dikatakan kurang jika frekuensi berolahraga <3kali/minggu dan berdurasi <30 menit sedangkan, olahraga dengan dikatakan cukup atau baik jika dilakukan sebanyak minimal $3 x /$ minggu dan berdurasi minimal 30 menit $^{8}$. Kurangnya aktivitas fisik seperti berolahraga dapat menyebabkan terjadinya kelebihan energi yang kemudian menjadi simpanan lemak di dalam tubuh. Remaja yang memiliki kebiasaan duduk tinggi tercatat yang mengalami obesitas sebesar $87,3 \%{ }^{9}$. Salah satu bentuk kegiatan yang menghabiskan waktu duduk yang tinggi adalah bermain internet atau media sosial. Menurut survei dari Global Web Index tahun 2016, ratarata orang dapat menghabiskan waktu selama 2 jam hanya untuk membuka media sosial ${ }^{10}$.

Seiring dengan perkembangan teknologi seperti gadget dan adanya akses media sosial menyebabkan seseorang semakin malas untuk melakukan aktivitas fisik salah satunya adalah berolahraga ${ }^{11}$. Konsep tehknolgi yakni membuat manusia menjadi mudah dan cepat dalam melakukan apapun, hal ini membuat manusia merasa dimanjakan dan membuat mereka menjadi malas untuk melakukan aktivitas fisik ${ }^{12}$. Remaja adalah kelompok yang tergolong tinggi dalam menggunakan media sosial khususnya dalam hal berkomunikasi dengan teman di situs jejaring sosial, mencari hiburan, dan informasi. Penelitian yang dari Sekolah Tinggi Sandi Negara (STSN) dan pihak Yahoo! terkait tingkat penggunaan internet pada remaja menunjukkan hasil bahwa remaja yang paling banyak menggunakan internet adalah remaja usia 15-19 tahun yakni sebesar $64 \%^{13}$. Menurut penelitian dari Perserikatan Bangsa-Bangsa (PBB) tahun 2014 didapatkan bahwa di Indonesia usia anak dan remaja aktif menggunakan internet dan jumlahnya diprediksi mencapai 30 juta.

Gaya hidup kurang gerak cenderung terus meluas dalam masyarakat berteknologi maju ${ }^{14}$. Peningkatan jumlah waktu yang dihabiskan untuk melalukan kegiatan menetap salah satunya adalah mengakses media sosial telah mengurangi jumlah waktu remaja yang dapat dihabiskan untuk melakukan aktivitas fisik $^{15}$. Menurut penelitian dari Symone tahun 2017, bahwa media sosial memiliki pengaruh terhadap perilaku kesehatan remaja, khususnya diet dan olahraga ${ }^{16}$. Sebagai generasi penerus bangsa, keadaan gizi pada remaja adalah hal yang penting karena akan mempengaruhi kondisinya di

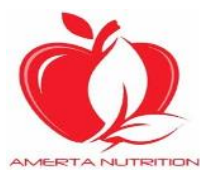

(C)2019. Fransiska, dkk. Open access under CC BY - SA license.

Received: 21-05-2019, Accepted: 10-07-2019, Published online: 09-9-2019.

doi: 10.20473/amnt.v3.i3.2019.142-148, Joinly Published by IAGIKMI \& Universitas Airlangga 
siklus kehidupan selanjutnya. Penelitian ini bertujuan meneliti hubungan antara intensitas penggunaan media sosial dengan kebiasaan olahraga serta kaitannya dengan terjadinya obesitas pada siswa/i di SMAN 6 Surabaya.

\section{METODE}

Penelitian ini bersifat observasional analitik dengan desain penenlian cross sectional. Lokasi penelitian yakni SMA Negeri 6 Surabaya dan waktu penelitian yakni bulan April sampai dengan Mei 2019. SMA Negeri 6 Surabaya dipilih sebagai lokasi penelitian karena berdasarkan hasil studi pendahulan terhadap siswa/I SMAN 6 Surabaya diperoleh bahwa prevalensi remaja dengan status gizi gemuk sebesar 15,8\%. Berdasarkan hasil tersebut dapat diketahui bahwa prevalensi remaja dengan status gizi gemuk menunjukkan nilai yang lebih tinggi dibandingkan dengan prevalensi remaja gemuk nasional tahun 2018 yaitu sebesar $9,5 \%$.

Populasi pada penelitian adalah semua siswa/i kelas X dan XI SMA Negeri 6 Surabaya. Besar sampel dihitung menggunakan rumus Lemeshowdan diperoleh besar sampel sebanyak 133 orang. Pengambilan sampel menggunakan Teknik cluster random sampling berdasarkan jumlah kelas $\mathrm{X}$ dan $\mathrm{X}$ di SMAN 6 Surabaya. Teknik undian dilakukan untuk memperoleh sampel penelitian. Sampel pada penelitian ini diambil dengan menyusun daftar-daftar kelas X-XI, lalu memberikan nomor urut untuk kelas-kelas tersebut dan pengundian dilakukan untuk menetapkan sampel. Kelas yang terpilih dalam pengundian, maka seluruh anggota kelas tersebut merupakan sampel penelitian.

Ada beberapa kriteria inklusi dalam penelitian ini, yaitu responden, berusia 15-17 tahun, tidak sedang sakit infeksi/kronis, tidak sedang menjalani diet khusus, dan telah menandatangani lembar persetujuan responden.

Pengumpulan data terdiri dari data antropometri yaitu meliputi berat badan dan tinggi badan untuk mengetahui status gizi yang ditetapkan berdasarkan Indeks Massa Tubuh (IMT) menurut Usia dengan standar antropometri adalah Standar World Health Organization (WHO) tahun 2005, data karakteristik responden seperti, jenis kelamin, usia, pendapatan orang tua, pekerjaan orang tua, dan pendidikan orang tua diperoleh melalui pengisian kuesioner identitas diri yang dilakukan oleh responden. Pengukuran intensitas penggunaan media sosial pada responden menggunakan pengisian kuesioner tertutup terkait frekuensi dan durasi penngunaan media social yang berisi 8 pertanyaan dan dinilai menggunakan skala Likert dengan skor 1-4 (tidak pernah, jarang, sering, dan sangat sering). Berdasarkan total skor maka dapat dikategorikan menjadi intensitas penggunaan media sosial rendah jika skor <6, sedang 6-12, dan tinggi 13-16. Pengukuran kebiasaan olahraga pada responden menggunakan kusioner IPAQ (International Physical Activity Questionnaire) dan dinilai berdasarkan kriteria METs, cut of point rendah <600 METs/menit, sedang 600 - 1499 $\mathrm{METs} /$ menit, dan tinggi $\geq 1500 \mathrm{METs} /$ menit $^{17}$. Analisis terhadap data menggunakan uji korelasi Spearman dengan data numerik untuk menganalisis hubungan intensitas penggunaan media sosial dan kebiasaan olahraga dengan status gizi remaja. Penelitian ini telah lolos kaji etik dengan No 069/HRECC.FODM/III/2019 dari komite etik penelitian Fakultas Kedokteran Gigi Universitas Airlangga.

\section{HASIL DAN PEMBAHASAN}

Jenis kelamin, umur, pendidikan orangtua, pekerjaan orangtua, dan pendapatan orangtua responden dmerupakan karakteristik responden yang diiteliti dalam penelitian ini. Distribusi karakteristik responden tersaji dalam Tabel 1.

Menurut Tabel 1 bahwa dari 133 responden, sebagian besar dari responden berusia 16 tahun yaitu sebesar $57,5 \%$. Lebih dari setengah responden adalah perempuan yakni sebesar $61,9 \%$ sedangkan, responden laki-laki sebesar $38,1 \%$. Pendidikan orangtua responden sebagian besar adalah SMA/se-derajat, ayah sebesar $46,3 \%$ dan ibu sebesar 50,7\%. Ayah dari reponden sebagian besar bekerja sebagai seorang karyawan swasta sebesar $38,8 \%$ dan ibu tidak bekerja sebesar $41 \%$. Tingkat pendapatan dari orangtua responden sebagian besar berada pada kuartil 2 yakni Rp3510.000- $\leq$ Rp5000.000 sebesar $29,1 \%$.

The Health Resources and Service Administrations Guidelines Amerika Serikat menyatakan bahwa remaja merupakan individu yag berada pada rentang usia 11-21 tahun dan dikelompokkan dalam tiga kelompok usia, yaitu remaja awal (11-14 tahun), remaja tengah (15-17 tahun), dan remaja akhir (18-21 tahun $)^{18}$. Besar kecilnya kebutuhan gizi remaja dipengaruhi oleh jenis kelamin karena pada laki-laki dan perempuan memiliki pertumbuhan dan perkembangan yang berbeda. Pada laki-laki biasanya memiliki kebutuhan gizi yang lebih tinggi dibandingkan perempuan karena tingkat aktivitas yang lebih tinggi pada laki-laki. Sedangkan, risiko obesitas pada perempuan lebih besar dibandingkan laki-laki. Hal tersebut disebabkan, karena remaja perempuan lebih banyak menyimpan massa lemak daripada laki-laki ${ }^{19}$. Memasuki masa pubertas, remaja perempuan mempunyai presentase lemak antara $22-26 \%{ }^{20}$. Penyedian bahan pangan dalam keluarga dipengaruhi oleh pendapatan keluarga, pendidikan terakhir, dan pekerjaan orang sehingga menentukan kualitas gizi dan status gizi keluarga, karena hal ini secara tidak langsung mempengaruhi pengetahuan akan gizi ${ }^{21}$.

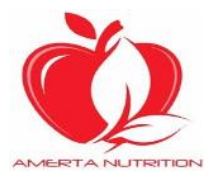

(C)2019. Fransiska, dkk. Open access under CC BY - SA license.

Received: 21-05-2019, Accepted: 10-07-2019, Published online: 09-9-2019. doi: 10.20473/amnt.v3.i3.2019.142-148, Joinly Published by IAGIKMI \& Universitas Airlangga 
Tabel 1. Karakteristik Responden

\begin{tabular}{|c|c|c|}
\hline \multirow[t]{2}{*}{ Variabel } & Jumlah & Presentase \\
\hline & $\mathrm{n}$ & $\%$ \\
\hline \multicolumn{3}{|l|}{ Usia } \\
\hline 15 tahun & 15 & 11.2 \\
\hline 16 tahun & 77 & 57,5 \\
\hline 17 tahun & 41 & 30,6 \\
\hline \multicolumn{3}{|l|}{ Jenis Kelamin } \\
\hline Laki-laki & 50 & 38,1 \\
\hline Perempuan & 83 & 61,9 \\
\hline \multicolumn{3}{|l|}{ Pendidikan Ayah } \\
\hline SD & 1 & 0,7 \\
\hline SMP & 2 & 1,5 \\
\hline SMA/se-derajat & 62 & 46,3 \\
\hline $\mathrm{D} 1 / \mathrm{D} 2 / \mathrm{D} 3$ & 8 & 6 \\
\hline $\mathrm{S} 1 / \mathrm{S} 2 / \mathrm{S} 3$ & 60 & 36,6 \\
\hline \multicolumn{3}{|l|}{ Pekerjaan Ayah } \\
\hline PNS & 15 & 11,2 \\
\hline Karyawan Swasta & 52 & 38,8 \\
\hline Wiraswasta & 30 & 22,4 \\
\hline Dokter & 2 & 1,5 \\
\hline Guru/Dosen & 6 & 4,5 \\
\hline TNI/POLRI & 8 & 5,9 \\
\hline Buruh & 1 & 0,7 \\
\hline Pedagang & 3 & 2,2 \\
\hline Lain-lain & 16 & 11,9 \\
\hline \multicolumn{3}{|l|}{ Pendidikan Ibu } \\
\hline SD & 3 & 2,2 \\
\hline SMP & 5 & 3,7 \\
\hline SMA/se-derajat & 68 & 50,7 \\
\hline $\mathrm{D} 1 / \mathrm{D} 2 / \mathrm{D} 3$ & 6 & 4,5 \\
\hline $\mathrm{S} 1 / \mathrm{S} 2 / \mathrm{S} 3$ & 51 & 34,3 \\
\hline \multicolumn{3}{|l|}{ Pekerjaan Ibu } \\
\hline PNS & 5 & 3,7 \\
\hline Karyawan Swasta & 27 & 20,1 \\
\hline Wiraswasta & 11 & 8,2 \\
\hline Dokter & 2 & 1,5 \\
\hline Dosen/Guru & 1 & 0,7 \\
\hline TNI/POLRI & 1 & 0,7 \\
\hline Pedagang & 1 & 0,7 \\
\hline IRT & 55 & 41 \\
\hline Lain-lain & 30 & 22,4 \\
\hline \multicolumn{3}{|l|}{ Pendapatan Orang tua } \\
\hline $\mathrm{Q} 1(\leq \mathrm{Rp} 3510.000)$ & 33 & 24,6 \\
\hline Q2( >Rp3510.000 - $\leq$ Rp5000.000) & 39 & 29,1 \\
\hline Q3 (>Rp5000.000 - $\leq$ Rp9210.000) & 28 & 20,9 \\
\hline Q4 (>Rp9210.000) & 33 & 24,5 \\
\hline
\end{tabular}

Status gizi pada remaja diperoleh melalui hasil pengukuran antropometri22. Indeks Massa Tubuh berdasarkan usia (IMT/U) direkomendasikan sebagai dasar indikator untuk menentukan status gizi pada remaja sampai usia 18 tahun $^{23}$. Berdasarkan hasil pengukuran antropometri yang dilakukan kepada responden, sebagian besar siswa SMAN 6 Surabaya berstatus gizi normal, namun terdapat juga siswa dengan status gizi kurang maupun lebih.
Berdasarkan Grafik 1, terdapat responden dengan status gizi gemuk sebanyak $14,3 \%$ dan obesitas sebanyak $6,8 \%$. Status gizi individu merupakan keseimbangan antara kecukupan dengan kebutuhan gizi. Apabila kecukupan gizi memenuhi kebutuhan gizi maka akan tercapai status gizi yang baik namun, jika terjadi ketidakseimbangan antara kecukupan dan kebutuhan gizi individu maka akan menyebabkan seseorang memiliki

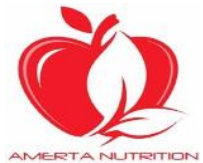

C2019. Fransiska, dkk. Open access under CC BY - SA license.

Received: 21-05-2019, Accepted: 10-07-2019, Published online: 09-9-2019.

doi: 10.20473/amnt.v3.i3.2019.142-148, Joinly Published by IAGIKMI \& Universitas Airlangga 
status gizi kurang atau lebih ${ }^{24}$. Berdasarkan penelitian ini prevalensi remaja dengan gizi lebih di SMAN 6 Surabaya lebih tinggi dibandingkan prevalensi status gizi kurang. Penemuan ini sejalan dengan data Riskesdas tahun 2018 bahwa masalah gizi yang mendominasi kelompok remaja usia 13-17 tahun adalah gizi lebih dan wilayah perkotaan merupakan wilayah paling banyak terdapat remaja dengan status gizi lebih ${ }^{4}$.

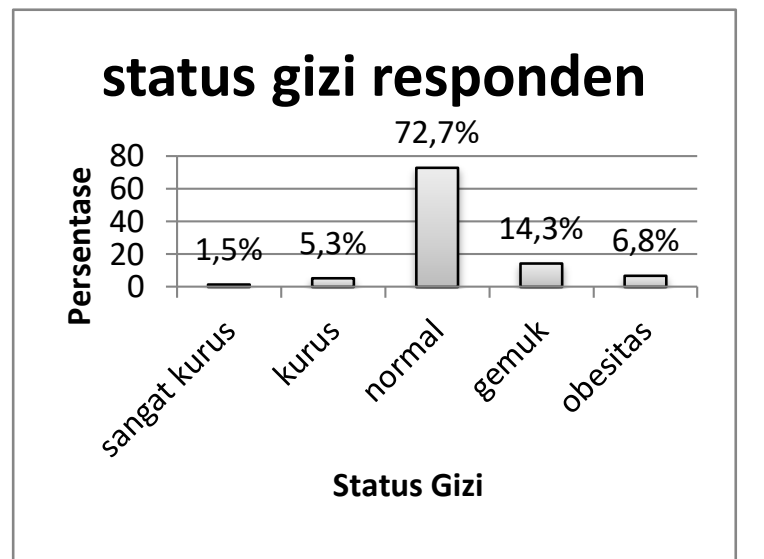

Gambar 1. Distribusi Status Gizi Siswa SMAN 6 Surabaya Tahun 2019

Menurut Tabel 2. menunjukkan bahwa pada responden dengan status gizi gemuk sebesar $14,3 \%$ maupun obesitas sebesar $6,8 \%$ memiliki prevalensi yang lebih tinggi dibandingkan remaja dengan status gizi sangat kurus sebesar $1,5 \%$ maupun kurus sebesar $5,3 \%$ dan pada remaja gemuk dan obesitas cenderung memiliki tingkat kebiasaan olahraga rendah yaitu sebesar $11,3 \%$ dan $4,5 \%$. Penelitian sejalan dilkukan pada siswa di SMK Muhammadiyah 2 Surakarta, ditemukan bahwa responden yang mengalami overweight yang memiliki kebiasaan olahraga kurang atau rendah yakni sebesar $75,6 \%$ dan pada responden tidak overweight rata-rata yang memiliki kebiasaan olahraga baik sebesar $56,1 \%$. Berdasarkan penelitian tersebut responden yang tidak overweight memiliki kebiasaan olahraga yang lebih baik atau tinggi. Seseorang dengan tingkat aktivitas fisik yang rendah memiliki Indeks Massa Tubuh diatas normal dan menyebabkan seorang tersebut berisiko mengalami masalah gizi lebih. Hal ini karena terjadi ketidakseimbangan energi dalam tubuh dalam jangka waktu yang lama, yaitu energi yang masuk tidak seimbang dengan energi keluar ${ }^{25}$.

Rendahnya kebiasaan dalam berolahraga dapat disebabkan oleh adanya berbagai saranan dan fasilitas dari kemajuan teknologi salah satunya adalah media sosial sehingga menyebabkan remaja malas untuk bergerak ${ }^{26}$. Penggunaan media sosial merupakan kegiatan yang membuat remaja harus duduk menetap selama waktu yang lama. Penggunaan media sosial dalam waktu yang lama, akan menyebabkan seseorang malas untuk bergerak sehingga pemakaian energi untuk berolahraga menjadi rendah. Dapat dilihat pada Tabel 3. bahwa responden dengan kebiasaan olahraga rendah adalah mereka dengan intensitas penggunaan media sosial tinggi sebesar $44,4 \%$, responden dengan intensitas penggunaan media sosial sedang mempunyaii kebiasaan olahraga sedang sebesar $23,3 \%$, sedangkan responden dengan intensitas penggunaan media sosial yang rendah mempunyai kebiasaan olahraga yang tinggi sebesar $1,5 \%$. Penelitian sejalan dari Sirajuddin terhadap remaja di Makassar, hasil menunjukkan bahwa sebesar $91,3 \%$ remaja aktif menggunakan media sosial tinggi mempunyai kebiasaan olahraga yang rendah sebesar $71,3 \%{ }^{27}$.

Tabel 2. Distribusi Kebiasaan Olahraga Dan Status Gizi Siswa SMAN 6 Surabaya Tahun 2019

\begin{tabular}{|c|c|c|c|c|c|c|c|c|c|c|c|c|}
\hline \multirow{3}{*}{ Kebiasaan Olahraga } & \multicolumn{12}{|c|}{ Status Gizi } \\
\hline & \multicolumn{2}{|c|}{ Sangat kurus } & \multicolumn{2}{|c|}{ Kurus } & \multicolumn{2}{|c|}{ Normal } & \multicolumn{2}{|c|}{ Gemuk } & \multicolumn{2}{|c|}{ Obesitas } & \multicolumn{2}{|c|}{ Total } \\
\hline & $\mathbf{n}$ & $\%$ & $\mathbf{n}$ & $\%$ & $\mathbf{n}$ & $\%$ & $\mathrm{n}$ & $\%$ & $\mathbf{N}$ & $\%$ & $\mathbf{n}$ & $\%$ \\
\hline Tinggi & 0 & 0 & 0 & 0 & 13 & 9,8 & 1 & 0,7 & 0 & 0 & 14 & 10,5 \\
\hline Sedang & 1 & 0,7 & 4 & 3 & 38 & 28,6 & 3 & 2,3 & 3 & 2,3 & 49 & 36,8 \\
\hline Rendah & 1 & 0,7 & 3 & 2,3 & 45 & 33,8 & 15 & 11,3 & 6 & 4,5 & 70 & 52,6 \\
\hline
\end{tabular}

Tabel 3. Distribusi Kebiasaan Olahraga Dengan Intensitas Penggunaan Media Sosial Pada Siswa SMAN 6 Surabaya Tahun 2019

\begin{tabular}{|c|c|c|c|c|c|c|c|c|}
\hline \multirow{3}{*}{ Kebiasaan Olahraga } & \multicolumn{8}{|c|}{ Intensitas Penggunaan Media Sosial } \\
\hline & \multicolumn{2}{|c|}{ Tinggi } & \multicolumn{2}{|c|}{ Sedang } & \multicolumn{2}{|c|}{ Rendah } & \multicolumn{2}{|c|}{ Total } \\
\hline & $n$ & $\%$ & $n$ & $\%$ & $\mathbf{n}$ & $\%$ & $\mathbf{n}$ & $\%$ \\
\hline Tinggi & 0 & 0 & 12 & 9 & 2 & 1,5 & 14 & 10,5 \\
\hline Sedang & 17 & 12,8 & 31 & 23,3 & 1 & 0,8 & 49 & 36,8 \\
\hline Rendah & 59 & 44,4 & 10 & 7,5 & 1 & 0,8 & 70 & 52,6 \\
\hline Total & 76 & 57,1 & 53 & 39,8 & 4 & 3 & 133 & 100 \\
\hline
\end{tabular}

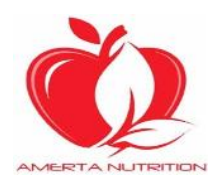

(C)2019. Fransiska, dkk. Open access under CC BY - SA license.

Received: 21-05-2019, Accepted: 10-07-2019, Published online: 09-9-2019.

doi: 10.20473/amnt.v3.i3.2019.142-148, Joinly Published by IAGIKMI \& Universitas Airlangga 
Hasil penelitian menunjukkan bahwa terdapat hubungan yang signifikan antara intensitas penggunaan media sosial dengan kebiasaan olahraga dengan nilai $p=0,000$ dan berdasarkan Gambar 2. bahwa terdapat hubungan yang negatif antara intensitas penggunaan media sosial dengan kebiasaan olahraga dengan nilai $r=-$ 0,475 , semakin tinggi intensitas penggunaan media sosial semakin rendah kebiasaan olahraga. Penelitian sejalan pada remaja menunjukkan bahwa terdapat hubungan yang signifikan antara penggunaan media sosial dengan kebiasaan olahraga pada remaja di Makassar dengan nilai $p=0,012$. Semakin tinggi penggunaan media sosial membuat kebiasaan olahraga remaja semakin rendah dan semakin besar pula risiko terhadap terjadinya obesitas

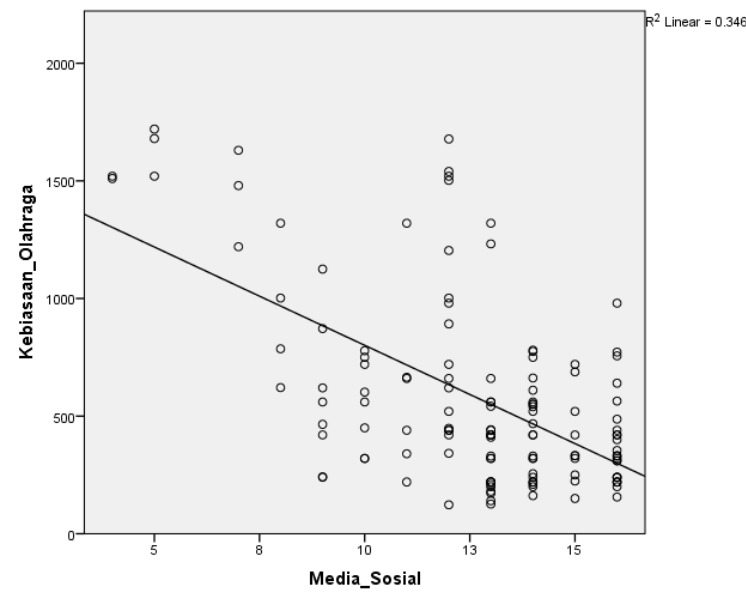

karena rendahnya energi yng dibakar melalui olahraga ${ }^{27}$.

Gambar 2. Scatter Plot Kebiasaan Olahraga Dengan Intensitas Penggunaan Media Sosial Pada Siswa SMAN 6 Surabaya Tahun 2019

Keterbatasan dalam penelitian ini yaitu analisis yang dilakukan adalah analisis bivariat terkait hubungan antara intensitas penggunaan media sosial dengan kebiasaan olahraga, tidak menganalisis terkait faktor lain yang juga berpengaruh pada kebiasaan olahraga responden seperti waktu luang dan fasilitas olahraga.

\section{KESIMPULAN}

Kesimpulan penelitian adalah ada hubungan antara kebiasaan olahraga yang rendah dengan intensitas penggunaan media sosial yang tinggi pada siswa/i di SMA Negeri 6 Surabaya. Intensitas penggunaan media sosial pada responden tergolong tinggi. Intensitas penggunaan media sosial yang tinggi dapat memberikan dampak negatif bagi remaja, salah satunya adalah membuat terjadinya penurunan aktivitas fisik yakni olahraga pada remaja. Rendahnya kebiasaan olahraga menyebabkan terjadinya ketidakseimbangan metabolisme dalam tubuh dan dapat berisiko terhadap peningkatan berat badan dan timbulnya obesitas.

Siswa dapat memanfaatkan media sosial sebagai media atau sarana untuk melakukan olahraga, baik saat di sekolah maupun di rumah contohnya melalui video yang terdapat di media sosial terkait olahraga dan melalui penyebaran informasi terkait olahraga yang tepat bagi remaja dan manfaat dari olahraga melalui media sosial.

\section{ACKNOWLEDGEMENT}

Peneliti mengucapkan terimakasih kepada wakil kepala sekolah SMA Negeri 6 Surabaya atas izin yang telah diberikan, siswa/i selaku responden penelitian, dan seluruh teman yang berkontribusi untuk membantu penelitian ini.

\section{REFERENSI}

1. Andriani,M., W. Pengantar Gizi Masyarakat. (Kencana Prenada Media Group, 2012).

2. Haq, A.B., Murbawani, E., A. Status Gizi, Asupan Makan Remaja Akhir Yang Berprofesi Sebagai Model. J. Nutr. Coll. 3, 489-494 (2014).

3. Andriani, M., Wirjatmadi, B. Peranan Gizi Dalam Siklus Kehidupan. (Kencana Prenada Media Group, 2012).

4. Kementerian Kesehatan Republik Indonesia. Laporan Nasional Riset Kesehatan Dasar 2018 (Report of Indonesian Basic Health Survey). (2018).

5. Choi, H., K., Atkinson, K., Karlson, E., W. \& Curhan, G. Obesity, Weight Change, Hypertension, Diuretic Use, and Risk of Gout in Men. Arch. Intern. Med. 165, 742-748 (2005).

6. Gouw, L. Associations Between Diet And Inactivity Behaviours With Overweight And Obesity Among 10-18 Years Old Czech Republic Adolescents. Public Health Nutrition. 13, 1701-1707 (2010).

7. Wiramihardja. Obesitas Permasalahan dan Terapi Praktis. (Sagung Seto, 2004).

8. Ardyana, D. Perbedaan Asupan Lemak Dan Kebiasaan Olahraga Pada Siswa Dengan Status Gizi Overweight Dan Non Overweight Di SMK Muhammadiyah 2 Surakarta. (Muhammadiyah Surakarta, 2016).

9. Miko, A. \& Dina, P., B. Hubungan Pola Makan Pagi dengan Status Gizi pada Mahasiswi Poltekkes Kemenkes Aceh. Aceh Nutrition Journal 1, 83-87 (2016).

10. Ariani, T., D. Hubungan Antara Intensitas Pnggunaan Media Sosial Dengan Pengungkapan Diri Pada Remaja. (Muhammadiyah Surakarta, 2018).

11. Kementerinan Kesehatan Republik Indonesia. Pedoman Pencegahan dan Penanggulangan Kegemukan dan Obesitas pada Anak Sekolah. Kementerian Kesehatan Republik Indonesia (2012).

12. Yudiningrum, F., R. Efek Teknologi Komunikasi Elektronik Bagi Tumbuh Kembang Anak. UNS Digital Library (2014).

13. Putri, W., S., R., Nurwati, N. \& Budiarti, M. Pengaruh Media Sosial Terhadap Perilaku Remaja. Prosiding Penelitian dan Pengabdian Masyarakat 3, (2016).

14. Mandriyarini, R., Sulchan, M. \& Nissa, C. Sedentary lifestyle sebagai risiko kejadian obesitas pada remaja SMA stunted di Kota Semarang. Journal of Nutrition College 6, 149-155 (2019).

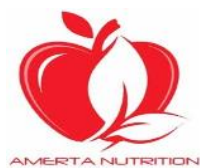

(C)2019. Fransiska, dkk. Open access under CC BY - SA license.

Received: 21-05-2019, Accepted: 10-07-2019, Published online: 09-9-2019.

doi: 10.20473/amnt.v3.i3.2019.142-148, Joinly Published by IAGIKMI \& Universitas Airlangga 
15. Bhadoria, A., S. et al. Childhood obesity: Causes and consequences. Journal of Family Medicine and Primary Care 4, 187-192 (2015).

16. Hoogstins, E., S. Modelling on Social Media: Influencing Young Adults' Food Choices. (LUNDS UNIVERSITET, 2017)

17. Craig, Marshall, A., Sjostrom, M., et al. Guidelines for Data Processing and Analysis of the International Physical Activity Questionnaire (IPAQ)-Short and Long Forms. www.Ipaq.Ki.Se (2005).

18. Kemala, I., N. Stress Pada Remaja. USU Repository (Universitas Sumatera Utara, 2007).

19. Farida, I. Faktor-faktor yang Berhubungan dengan Perilaku Konsumsi Buah dan Sayur pada Remaja di Indonesia Tahun 2007. FKIK UIN Syarif Hidayatullah (Universitas Islam Negeri Syarif Hidayatullah Jakarta, 2010).

20. Sutriani, A., Ngadiarti, I. Hubungan Antara Asupan Energi, Protein, Lemak, Karbohidrat, Serat dengan Kejadian Gizi Lebih Pada Anak Remaja Usia 13-18 Tahun di Pulau Jawa. Nutrition Diatita 5, 68-80 (2013).

21. Amirudin, M., M., Nurhayati, F. Hubungan Antara
Pendapatan Orang Tua Dengan Status Gizi Pada Siswa SDN II Tenggong Rejotangan Tulungagung. Jurnal Pendidikan Olahraga dan Kesehatan 02, 564-568 (2014).

22. Rachmayani, S., A. Hubungan Asupan Zat Gizi dan Status Gizi Remaja Putri di SMK Ciawi Bogor. Indonesian Journal of Human Nutrition. 5, 125-130 (2018).

23. Rokhmah, F., Muniroh, L. Hubungan Tingkat Kecukupan Energi Dan Zat Gizi Makro Dengan Status Gizi Siswi Sma Di Pondok Pesantren Al-Izzah Kota Batu. Media Gizi Indonesia. 11, 94-100 (2016).

24. Almatsier, S. Prinsip Dasar Ilmu Gizi. (PT Gramedia Pustaka Utama, 2006).

25. Octari, C., Liputo, N. I. \& Edison. Hubungan Status Sosial Ekonomi dan Gaya Hidup dengan Kejadian Obesitas pada Siswa SD Negeri 08 Alang Lawas Padang. Jurnal Kesehatan Andalas 3, 131-135 (2014).

26. Salbe, A. D. Relation between physical activity and obesity. American Journal of Clinical Nutrition. 78, 193194 (2003).

27. Sirajuddin, A. Kelebihan Berat Badan Dipicu Oleh Aktivitas Media Sosial Pada Remaja. Media Kesehatan Politeknik Kesehatan. 12, (2017). 